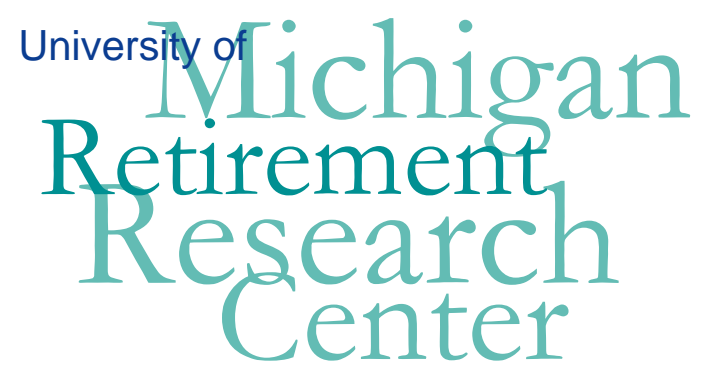

Working Paper WP 2005-094

\title{
Saving Shortfalls and Delayed Retirement
} Andrew Au, Olivia S. Mitchell, and John W.R. Phillips

\begin{tabular}{|c|c|}
\hline $\mathrm{M}$ & $\mathrm{R}$ \\
\hline $\mathrm{R}$ & $\mathrm{C}$ \\
\hline
\end{tabular}$\quad$ Project \#: UM04-C1 


\title{
"Saving Shortfalls and Delayed Retirement"
}

\author{
Andrew $\mathrm{Au}$ \\ Wharton School, University of Pennsylvania \\ Olivia S. Mitchell \\ Wharton School, University of Pennsylvania \\ John W.R. Phillips \\ National Institute on Aging
}

January 2005

\author{
Michigan Retirement Research Center \\ University of Michigan \\ P.O. Box 1248 \\ Ann Arbor, MI 48104
}

\section{Acknowledgements}

This work was supported by a grant from the Social Security Administration through the Michigan Retirement Research Center (Grant \# 10-P-98358-5). The opinions and conclusions are solely those of the authors and should not be considered as representing the opinions or policy of the Social Security Administration or any agency of the Federal Government.

\section{Regents of the University of Michigan}

David A. Brandon, Ann Arbor; Laurence B. Deitch, Bingham Farms; Olivia P. Maynard, Goodrich; Rebecca McGowan, Ann Arbor; Andrea Fischer Newman, Ann Arbor; Andrew C. Richner, Grosse Pointe Park; S. Martin Taylor, Gross Pointe Farms; Katherine E. White, Ann Arbor; Mary Sue Coleman, ex officio 


\title{
Saving Shortfalls and Delayed Retirement
}

\author{
Andrew Au \\ Olivia S. Mitchell \\ John W.R. Phillips
}

\begin{abstract}
Prior research has suggested that many older Americans have not saved enough to maintain consumption levels in old age. One way older persons might respond to inadequate savings would be to extend their worklives by delaying retirement. This paper examines evidence on this matter using the Health and Retirement Study, a nationally representative panel survey of people age 51-61 in 1992 followed for several years in a panel. We use the data to project household retirement assets and to determine how much more saving would be needed to preserve post-retirement consumption levels. Our research then examines the links between derived saving shortfall measures and delayed retirement patterns. Among nonmarried persons, there is evidence that larger shortfalls do produce delayed retirement, though the effect is not quantitatively large. For married couples, pre-retirement wealth shortfalls do not appear to be significantly associated with delayed retirement. Evidently couples have other means of handling saving shortfalls.
\end{abstract}

\section{Authors' Acknowledgements}

$\mathrm{Au}$ is a doctoral candidate in the Insurance and Risk Management Department at the Wharton School, University of Pennsylvania. Mitchell is a Research Associate of the NBER; International Foundation of Employee Benefit Plans Professor of Insurance and Risk Management; and Executive Director of the Pension Research Council and Director of the Boettner Center at the Wharton School, University of Pennsylvania. Phillips is an economist at the National Institute on Aging. This paper was presented at the August 2004 meeting of the Retirement Research Consortium in Washington, DC. We thank David Wise and other meeting participants for useful comments. This is a draft: comments are welcome. The authors retain full responsibility for all views contained herein. (c) $2005 \mathrm{Au}$, Mitchell, and Phillips. 


\section{Introduction}

Much has been written in the economics literature about the determinants of household wealth accumulation, particularly regarding the question of whether households save adequately for their retirement. ${ }^{1}$ In this paper, we measure and link the extent of retirement shortfalls to the decision to delay retirement. In particular, we ask whether older households which appear to lack the wealth to retire at a given age actually extend their working lives, so as to more readily pay for an adequate retirement income. Evidence on retirement wealth adequacy is of particular interest given the rapidly aging workforce and the expectation that Social Security faces financial insolvency.

There are various benchmarks against which household wealth levels might be compared, to determine retirement saving adequacy. One is derived from a structural model of lifecycle utility maximization which generates estimates of projects saving shortfalls. For example, over a decade ago Bernheim (1992) used dynamic programming to solve for optimal asset accumulation patterns. At that time, his data indicated that households age 35-45 accumulated assets at only one-third the rate of what was needed to maintain consumption levels during retirement; overall, Bernheim reported saving shortfalls averaging 9-19 percent per year. Other research in the field has reached more optimistic conclusions, including Sabelhaus and Manchester (1995) who noted that baby boomers were accumulating more assets than their parents, even though their consumption patterns appeared similar. Using a newer dataset, Engen et al. (2004) also adopt a life cycle model and found smaller saving shortfalls among older households than did Bernheim

\footnotetext{
${ }^{1}$ Older studies in this vein include Kotlikoff et al. (1982); Bernheim (1988); and many others reviewed in Lumsdaine and Mitchell (1999). A spate of recent studies includes work by Aguiar and Hurst (2004); Banks et al. (1998); Engen and Gale (1999); Engen et al. (2004); Haider and Stephens (2004); Hurd and Rohwedder (2003); Hurst (2004); Mitchell and Moore (1998); Moore and Mitchell (2000); and Scholz et al. (2003).
} 
in the earlier surveys. A recent study by Scholz et al. (2003) elaborates the life cycle model to incorporate additional sources of uncertainty including medical costs. Again using recent data, that study did document some saving shortfalls, although for most American households retirement assets appeared adequate.

This literature comes to somewhat disparate conclusions regarding the shortfalls issue for a variety of reasons. One is the fact that these studies differ with regard to how they model workers' preferences for leisure and purchased goods. A second is that some authors exclude from consideration important components of retiree wealth such as net housing equity (and sometimes Social Security or pensions). A third difference stems from the use of different benchmarks as a "baseline” for consumption-smoothing. In general, studies that take lifetime earnings as the benchmark tend to find better adequacy rates than do studies which focus on preretirement earnings as the target for replacement. Which is the most appropriate level is, of course, unclear on a priori grounds.

A different approach is adopted by Mitchell and Moore (1998) and Moore and Mitchell (2000; hereafter MM), an approach that we extend in the present paper. That methodology builds on a financial planning approach, where a "replacement rate" consumption target is converted into a consumption-smoothing path consistent with a life cycle model. It is worth noting that most financial advisers adopt a pre-specified replacement rate, for instance proposing that households should have assets sufficient to generate lifetime annual income worth $75 \%$ of pre-retirement pay in order to avoid a shortfall. ${ }^{2}$ By contrast, MM solve for an endogenous replacement rate endogenously, one which derives from the hypothesis that forward-looking

\footnotetext{
${ }^{2}$ Alternative computations adjust retirement consumption to exclude work-related expenses and to account for differential taxation of workers versus retirees (for a good discussion see McGill et al. 2004).
} 
households seek to maintain equal real, after-tax, after-saving, levels of pre- and post- retirement consumption. In this framework, a household's target replacement rate is determined as a function of household earnings and current wealth, as well as demographic information. The earlier MM results indicated that the median US household on the verge of retirement would need to save substantially more in order to retire at 62 , though this rate is approximately halved if retirement were delayed to age 65 . That research also found that saving shortfalls declined empirically as assets rose, but high earners had substantial undersaving.

In the present context, we posit that a household could respond to prospective retirement saving shortfalls in several ways. For example, imagine that a worker planned to retire at age 62, but sometime in his 50's, he determined that he had not saved enough to provide for a smooth consumption path in retirement. One response might be to stick with the target retirement age but save more, a strategy that would require consumption cuts and increased work effort. Another response might be for the older worker to plan on cutting post-retirement consumption. ${ }^{3}$ Yet a third possibility might be to work longer, and indeed most people retiring at age 62 are apparently in good enough health to do so. ${ }^{4}$ Further, the results from MM suggest that delaying retirement can substantially reduce the savings shortfalls.

\footnotetext{
${ }^{3}$ Some evidence does suggest that older workers do anticipate reducing consumption after retiring (Hurd and Rohwedder, 2003); on the other hand, Agiar and Hurst (2004) find that expenditures fall after retirement but consumption does not, due to increases in home production.

${ }^{4}$ That is, most HRS respondents retiring around age 62 do not report having work-limiting health problems. Burkhauser et. al (1996) first examined the health and economic circumstances of early Social Security beneficiaries, analysis extended by Mitchell and Phillips (2000) who use four waves of HRS data and consider a broader set of health measures. Both studies find that the majority of early retirees report themselves in good health.
} 
In what follows, we relate projected retirement savings shortfalls to observed retirement behavior in the HRS, to evaluate their association. ${ }^{5}$ We begin by assessing the claim that Americans undersave for retirement by examining the Health and Retirement Study, which contains exceptionally complete information on household wealth linked to administrative records on earnings and benefits from Social Security, including information on financial wealth, net home equity, and retirement pension wealth. With these data, we project and evaluate household retirement wealth, which we then compare to the level of retirement assets needed to smooth real consumption levels over the retirement period. We use this information to calculate the additional amount of annual earnings that would have to be saved to achieve consumption smoothing by the age of retirement. Finally we relate these shortfall measures to the probability of working at ages 62 and 65.

\section{Data and Methods}

Health and Retirement Study (HRS) respondents were first interviewed in 1992 at age 51-61 (along with spouses of any age); additional surveys have been administered every two years thereafter. ${ }^{6}$ In the HRS, retirement assets may be divided into three categories:

1. Financial wealth: business assets, financial assets (such as stocks, bonds, and bank accounts less outstanding debt), dedicated retirement assets including IRA and Keogh Accounts, and miscellaneous other financial assets;

\footnotetext{
${ }^{5}$ Our research is therefore similar in spirit to previous work (Bernheim 1988) which relied on the older Retirement History Survey (RHS) but did not use shortfall measures as we have done here. ${ }^{6}$ The present study uses all waves from 1992-2002; the 2004 data are not yet publicly available. Many of our analysis variables come from the Rand HRS, a user-friendly version of the HRS produced by the Rand Corporation with financial support from the National Institute on Aging and the Social Security Administration and technical support from the HRS staff at the Institute for Social Research. For more information, see http://hrsonline.isr.umich.edu/data/index.html.
} 
2. Net home equity for homeowners: the market value of owner-occupied housing less outstanding mortgage debt;

3. Retirement pension wealth: equal to the actuarial present value of future social security retirement and survivor benefits and employer pension benefits. ${ }^{7}$

To derive the retirement saving shortfall measures, we use the HRS asset information to derive two values (as per MM): each household's projected shortfall for retirement at 62, and also at age 65. ${ }^{8}$ The replacement rate equation sets net (after-tax) income pre-retirement equal to net income post-retirement. This may be expressed as:

$$
Y_{P}-T_{P}-S=Y_{F}-T_{F},
$$

where income $(Y)$, taxes $(T)$ and saving $(S)$ are considered both before retirement $(P)$ and post retirement $(F)$.

Equation (1) can be rearranged and written in terms of a consumption smoothing replacement rate $(R R)$ by dividing through by pre-retirement income and expressing savings as a proportion of pre-retirement income to generate equation (2).

(2) $\quad R R=\frac{Y_{P}(1-s)-T_{P}+T_{F}}{Y_{P}}=\frac{Y_{F}}{Y_{P}}$

Using an annuity factor $(A F)$ we convert the future income stream to the level of wealth required to sustain $Y_{F}{ }^{9}$ If a household's projected assets (PROJ) are less than their needs, they

\footnotetext{
${ }^{7}$ For detail on how these values are derived using linked data on company pensions and Social Security administrative records, see Gustman et al. (1999). The entire value of home equity is included in these measures, though we recognize that there is some controversy about whether the entire home asset should be counted. For instance Venti and Wise (2001) find that incomepoor but house-rich older families are more likely to reduce equity when they move, while house-poor but income-rich households tend to increase housing equity.

${ }^{8}$ Both measures are computed here using pre-retirement pay as the benchmark; see Appendix for a discussion of why using average lifetime pay as the benchmark is problematic.

${ }^{9}$ Annuity factors are calculated using the same assumptions used to calculate the value of Social Security wealth and rely on the intermediate assumptions used by the Social Security Administration. For more information, see MM 2000.
} 
need to save the difference between the current period and their retirement age. The difference can be defined as:

$$
A F * Y_{F}-P R O J=A F^{*}\left[Y_{P} *(1-s)-T_{P}+T_{F}\right]-P R O J .
$$

Given the difference between projected and adequate level of assets and the number of years to retirement, we can calculate the percentage of earnings that must be saved in each year leading to retirement to meet the adequate level of assets. ${ }^{10}$ We solve for saving and replacement rates simultaneously using an iterative approach. The approach selects an initial replacement rate target and then solves for the target wealth level needed to finance this goal, allowing for differential taxation prior to retirement and during retirement. If household assets would be projected to fall short relative to target assets, the method derives the shortfall saving rate, which

${ }^{10}$ As mentioned in the text, one explanation for the disparate conclusions reached by prior studies in the savings adequacy literature is that each employs different benchmarks. For instance, some studies, including ours, focuses on replacing a portion of pre-retirement earnings, while others focus on replacing a portion lifetime earnings. A lifetime earnings benchmark is not used because of the data and assumptions required to modify the earnings benchmark. The identification of the prescribed savings rate in MM relies on the following equation:

$$
A F *\left[Y_{p}(1-s)-T_{p}+T_{F}\right]-P R O J=s * Y_{c} *\left[\sum_{i=0}^{T-t}(1+w g)^{\prime}(1+r)^{T-t-i}\right],
$$

where the left hand side of the equation is the amount of wealth that must be accumulated to reach the specified benchmark by retirement, the right hand side is the wealth accumulation process from the current period to retirement, $w g$ is an assumed wage growth, and $r$ is an assumed rate of return on savings. A key to this strategy is the fact that pre-retirement prescribed savings rate appears on both the left and right hand sides of the equality, so we can solve for the savings rate as a function of pre-determined arguments. This strategy breaks down when we substitute in the lifetime earnings benchmark. If we set average post-tax and post-savings lifetime earnings as the benchmark, then the above equation is modified to:

$$
A F *\left[\bar{Y}\left(1-s^{\prime}\right)-\bar{T}+T_{F}\right]-P R O J=s * Y_{c} *\left[\sum_{r=0}^{T=1}(1+w g)^{\prime}(1+r)^{r-1-1}\right],
$$

where $\bar{Y}$ is average lifetime earnings, $\bar{T}$ is average lifetime taxes, and $s$ ' is defined as the proportion of average lifetime income that is saved, not as a proportion of pre-retirement income as it is defined in the previous equation. The prescribed savings rate, $s$, is no longer identified as a function of pre-determined arguments unless. In order to define $s$ ' we would need information on savings historic savings patterns (which we do not observe in the data) or exogenously identify s' under a host of assumptions. For these reasons, in the present analysis we limit our analysis to the benchmark that focuses on pre-retirement earnings. 
is equal to the additional fraction of earnings that would have to be saved, to reach the consumption-smoothing goal. This new rate is then used to compute a new replacement rate: if the saving rate is unfeasibly high, the replacement rate is lowered; conversely, the prescribed replacement rate is increased if the saving rate proves below that required for consumption, taxes, and saving to sum to pre-retirement income. The process is repeated until the prescribed saving and replacement rates converge.

In the analysis to follow, we express shortfalls as percentage measures: that is, they refer to the additional fraction of pre-tax earnings that each household would have to save prior to retirement to smooth consumption over the remaining lifetime (hereafter "shortfall”). ${ }^{11}$

The next issue to which we turn is an examination of how these saving shortfalls might influence subsequent work and retirement behavior. In practice, there are many different ways to calibrate and quantify retirement behavior at older ages (c.f. Lumsdaine and Mitchell 1999; Gustman et al., 1995; Gustman and Steinmeier 2000). In the present analysis, we focus on two objectively measured and clearly work-related outcomes, namely, whether respondents reported themselves as working for pay at age 62 and also at age $65 .{ }^{12}$ For the first analysis sample, we select all respondents who attained at least age 62 by 2002, the last year of publicly available HRS dataset. For the second analysis, the sample includes only those who attained at least age 65 by 2002. Selecting our samples in this way avoids incomplete spells due to sample censoring. Both samples include only respondents who initially reported themselves as working for pay at baseline, in 1992.

\footnotetext{
${ }^{11}$ These computations take into account the household's tax status and life expectancy as of retirement age, using appropriate annuity factors and tax schedules in place at the time of the initial baseline; see Moore and Mitchell (2000).

${ }^{12}$ We have also examined alternative definitions of retirement, including whether or not the respondent had positive earnings; results were qualitatively similar to those reported below.
} 
The specific estimating equations we evaluate focus on $\operatorname{Prob}(W o r k \mid a)$, defined as the probability of working at age $a$, which equals 1 if the individual reported himself as working at the time of the survey and 0 otherwise:

$$
\operatorname{Prob}(\text { Work } \mid a)=f\left[\text { Shortfall, } X_{1}, X_{2}, X_{3}\right] \text {. }
$$

Our canonical regressions include the household's computed shortfall measured in three alternative ways. The first two refer to the shortfalls associated with retirement at a particular age (for age 62, SAVE62, and for age 65, SAVE65); these appear only in the equations relating to work at age 62 and 65 respectively. We also calculate SAVEDIFF which is change in the shortfall if the respondent were to work from age 62 to 65 ; this is included as a control in some of the specifications for work at age 62 .

The estimated coefficients from these variables help test the following hypotheses:

1. The probability of working at age 62 (or 65 ) is positively correlated with shortfalls (i.e., estimated coefficients $>0$ for SAVE62 and SAVE65).

2. The probability of working at age 62 is positively correlated with returns for working longer (i.e. estimated coefficient $>0$ for $S A V E D I F F$ ).

We also include a vector of standard socioeconomic variables $\left(\mathrm{X}_{1}\right)$ all measured at the 1992 baseline wave of the survey, including the respondent's educational attainment, marital status, number of children, race/ethnicity, and health.

Additional analysis adopts more complete specifications that add some less conventional variables to the canonical set:

- $\mathrm{X}_{2}$ includes an indicator of the respondent's reported financial planning horizon and a baseline indicator of the respondent's expectation of consumption declines in retirement. 
- $\mathrm{X}_{3}$ includes indicators of health and marital shocks, indicating whether he experienced a change in health, or became a widow/er since the baseline interview.

The empirical models are carried out separately for nonmarried versus married respondents. In the married respondent equations, we include controls for characteristics of their spouses. ${ }^{13}$ (A complete variable list appears in Appendix Table 1.)

\section{Empirical Results}

A graphical depiction of the distribution of shortfalls for our sample appears in Figure 1, for both age 62 and 65 retirement. ${ }^{14}$ The perpendicular line through the middle of both panels marks the zero shortfall point: the density to the left of the line indicates households who have saved enough to meet their retirement needs, while the opposite is true for households to the right of the line. Note that for both age 62 and 65 retirements, the distribution of shortfalls is skewed. Some households have saved considerable wealth relative to their needs (depicted by the relatively long left tail in each panel in Figure 1), but the majority of households fall to the right side of the distribution, indicating undersaving relative to consumption needs. It is also worth note that delaying retirement shifts more of the distribution to the left of the zero shortfall line and reduces the median shortfall: delaying retirement both eliminates and reduces shortfalls for many households. However, even with a delay in retirement, many households still experience shortfalls.

Figure 1 here

\footnotetext{
${ }^{13}$ Since married age-eligible respondents appear twice in the data, standard errors are adjusted for clustering in the married respondent specifications.

${ }^{14}$ We used the kernel density estimation available in STATA 8 SE. Weighting for the density estimate was produced with a Gaussian kernel and an optimally selected width.
} 
The overall distribution of shortfalls hides considerable dispersion across groups by marital status, wealth and earnings as indicated in Table 1. The first panel reports saving rates required to smooth consumption, provided separately for married and nonmarried households and arrayed by wealth quintile. ${ }^{15}$ The results show that the median married household on the verge of retirement in the HRS, at around age 56, would need to save 17 percentage points more of its current earnings to smooth consumption if retirement were to take place at age 62 . The shortfall for the median married household is reduced by $40 \%$, to only 10 percentage points, if retirement were postponed to age 65. For nonmarried individuals, the median shortfall for age-62 retirement is larger ( $24 \%$ of earnings) than for married households, but here, the gap can be more than halved by delaying retirement to age $65 .{ }^{16}$ Not surprisingly, shortfalls across the wealth distribution are uneven: the top wealth quintile already has enough to finance smooth consumption, while the poorest quintile faces the largest shortfalls. In the second panel, we array shortfalls by household earnings quintiles. Here the medians are similar: married couples would need to save $17 \%$ more per year if they intended to retire at age 62 , but only about half that much for retirement at age 65; nonmarried respondents have higher needs. It is also of interest to note that many low earners actually have negative shortfalls; that is, their combined assets and retirement benefits are already sufficient to consumption-smooth. By contrast, many higher earners can anticipate higher shortfalls, because they need to save more to maintain their high incomes into retirement.

Table 1 here

\footnotetext{
${ }^{15}$ Values of baseline wealth quintiles are given in \$2003, where values include net financial wealth, net home equity, and retirement wealth.

16 These shortfall figures are somewhat higher than those reported in MM (2000) due to fact that here we use a slightly older sample (age 52+) in order to ensure that there is no age-based censoring of the dependent variables used below.
} 
Next, we turn to an examination of the association between estimated shortfalls and the probability of working at age 62 and age 65 . Here the dependent variable is set to one if a respondent reported himself as working when surveyed at that age, and zero otherwise. Since the dependent variable is measured at the time the respondent was age 62 (or 65), the sample size depends on how many respondents were of the proper age for the measure in question. Our hypothesis regarding a relationship between shortfalls and work is predicated on the hypothesis that households consider their wealth needs and plan their retirement accordingly.

Before summarizing the econometric results, a glance on Figure 2 shows the relationship between respondents' actual work patterns to their ex-ante self-reports of the probability that they will be working at later ages (an assessment offered at baseline). In the top panel, we compares projected and actual probabilities of working at age 62 and 65 for nonmarried respondents, while the bottom panel depicts the same variables for married respondents. It is interesting that ex-ante work probabilities offered by nonmarried persons do a remarkably good job of tracking their ex-post work probabilities at age 62, implying that age 62 work expectations are typically met for nonmarried respondents. At age 65, the difference between ex-ante and $e x$ post work probabilities for nonmarrieds is about -5 percentage points, indicating if anything some earlier than expected retirement for this population. By contrast, the pattern is the opposite for the married groups, though the differences between the ex-ante versus the ex-post work probabilities are less than 5 percentage points. In any event, married respondents appear to slightly understate their probability of actually working at both ages, thought the effect is small. In sum, Figure 2 suggests that most peoples' expectations regarding work in later life turn out to be realized, at least for HRS respondents: that is, most people stick to their retirement plans. Figure 2 here 
To further analyze the relationship between shortfalls and delayed retirement, next we link the empirically observed probabilities of work at older ages to the household's computed shortfall measures. Three specifications are evaluated for both nonmarried and married households. In the first, we use only the relevant shortfall measure and include controls for socioeconomic variables $\left(\mathrm{X}_{1}\right)$ for respondents (as well as spouses, where relevant). In the second, we add variables indicating each respondent's reported financial planning horizon and a baseline indicator of his expectation of consumption declines in retirement $\left(\mathrm{X}_{2}\right)$. Finally, in our third specification, we add some controls for "shock" variables, which are indicators of health and marital changes experienced since the baseline interview. ${ }^{17}$

Results for the nonmarried respondents are provided in Table 2 and for married respondents in Table 3. For the nonmarried individuals, the first three columns describes results for the probability of working at age 62 (the second set focuses on work at 65); each of the three columns represents one of the three specifications described earlier. That is, $\mathrm{X}_{1}$ is the canonical specification which includes only the shortfall and socioeconomic variables; in turn, the later columns add $\mathrm{X}_{2}$ (planning and consumption expectation variables), and $\mathrm{X}_{3}$ adds shock variables. Table 2 here

The results show that all three specifications, and for both work at both ages 62 and 65, larger shortfalls are positively and statistically significantly associated with delayed retirement. Furthermore, this group is more likely to continue working at older ages if, by doing so, they close more of the shortfall gap (Savediff). Both findings are consistent with the hypothesis that older workers respond by working additional years when retirement assets are insufficient. Coefficients for education and health in the canonical specification $\left(\mathrm{X}_{1}\right)$ also have the expected

\footnotetext{
${ }^{17}$ Variable definitions appear in Appendix Table 1 and summary statistics appear in Appendix Table 2.
} 
signs: that is, respondents who are healthy, well-educated, and who anticipate living to age 75 with high probability all work longer. Those who were divorced prior to 1992 are also more likely to work at both age 62 and 65 . Being widowed has differential impacts depending on when it happens: widowhood prior to 1992 reduces the likelihood of working beyond age 62, but people who are widowed in their 50s appear more likely to work to age 65.

Another interesting finding is that our enriched specification (which includes the $\mathrm{X}_{2}$ vector) produces many statistically significant variables. Thus respondents who say they have relatively long financial planning horizons are also likely to work more at both ages 62 and 65. By contrast, the effect of expected consumption declines in retirement have different relationships with work at age 62 and 65. Expecting to consume less in retirement is positively correlated with more work at age 62, but the relationship turns negative for work at age 65. One possible explanation for this finding is that the returns to consumption of working longer diminish with age, such that delaying retirement leisure after age 65 is felt to be economically 'not worth it'.

In the third specification we add health and widowhood shock variables to the equation $\left(\mathrm{X}_{3}\right)$. For both the age 62 and 65 work equations, these new variables are both statistically significant and have the expected signs: shocks are correlated with lower probabilities of work. Again, the shortfall variables maintain their sign and significance. For the nonmarried sample, higher shortfalls are associated with higher work probabilities.

Results for married respondents appear on Table 3, with the first panel focusing on work at age 62 and the second, age 65 . The contrast with nonmarried respondents is stark: few variables are significant and this includes the shortfall variables. Some variables such as education and health shocks do tend to be statistically significant and have the expected signs, 
but these are the exceptions. In all, relatively few of the remaining variables in Table 3 are significant across specifications for the married sample.

Table 3 here

The results from Tables 2 and 3 are reduced form in nature, so they cannot directly identify causal relationships in the work/saving nexus. Yet they do suggest that the hypothesis of a positive empirical link between shortfalls and delayed retirement can only be accepted for the sample of nonmarried respondents. This may be due to the fact that married couples can adjust along a number of margins as described by Kotlikoff and Spivak (1981), including more work by other family members, small reductions in expenditures by more members, and the like.

We also find that the effects of shortfalls on retirement among nonmarried respondents is rather small quantitatively. Figure 3 provides predicted probabilities of work at age 62 and 65 for nonmarried respondents, assuming both zero and median levels of retirement shortfalls. What the results show is that the coefficients for SAVE62, SAVE65, and SAVEDIFF are all highly significant, but their magnitudes are quite small: predicted percentage changes are all less than 1 percent across specifications. Therefore, while a relationship between shortfalls and work exists, the magnitude of the effect appears to be quite small. Evidently people facing retirement saving shortfalls do not appear to delay retirement much; rather, they are likely to adapt to shortfalls along other dimensions. Additional research on consumption changes and possibly unretirement patterns would likely be valuable in examining these issues further.

\section{Conclusions and Future Research}

This paper explores links between retirement saving shortfalls and work at older ages using the Health and Retirement Study, a nationally representative survey of older Americans on 
the verge of retirement. The results show that the median older US household will be unable to maintain levels of pre-retirement consumption into retirement without additional saving, though delaying retirement by only three years would cut the saving burden by roughly half. We also find that saving shortfalls are distributed unevenly across the older population, such that those with the highest earnings categories are also those with the largest shortfalls. When we link our measures of shortfalls to the likelihood of working at older ages, we find that nonmarried households who face substantial saving shortfalls do tend to work somewhat longer. The estimates are robust to controls on a host of other factors, though the magnitude of the estimated effects is quantitatively small. Among married couples, we find no statistically significant relationship between shortfalls and work. One reason for the difference in results for the married and nonmarried samples may be that two earners can each work a bit longer, or consume a bit less, whereas nonmarried persons must bear the burden of the entire shortfall alone.

Though the current literature is, to some degree, divided on the extent of saving adequacy among near-retirees, our results suggest that individuals do respond rationally to saving shortfalls by extending their worklives and reducing the period they will spend in retirement. Future research can take into account differences in respondent knowledge regarding their anticipated retirement benefits (cf Gustman and Steinmeir, 2001a and b). 


\section{References}

Aguiar, Mark and Erik Hurst. 2004. “Consumption vs Expenditure”. NBER WP 10307 February.

Banks, James, Richard Blundell, and Sarah Tanner. 1998. “Is There a Retirement Savings

Puzzle?” AER September (4): 769-788.

Bernheim, B. Douglas, 1992. Is the Baby Boom Generation Preparing Adequately for

Retirement? Technical Report. Princeton, N.J., Merrill Lynch.

Bernheim, B. Douglas. 1989. “The Timing of Retirement: A Comparison of Expectations and Realizations”. In David A. Wise, editor. The Economics of Aging. Chicago: University of Chicago Press for National Bureau of Economic Research. Pp. 335-355.

Burkhauser, Richard V., Kenneth A. Couch, and John W. Phillips. 1996. "Who Takes Early Social Security Benefits: the Economic and Health Characteristics of Early Beneficiaries”. The Gerontologist, 36(6): 789-799.

Gustman, Alan L., Olivia S. Mitchell, and Thomas L. Steinmeier. 1995. "Retirement Measures in the Health and Retirement Study.” Journal of Human Resources, Vol. 30, Suppl, pp. S57-83.

Gustman, Alan L., Olivia S. Mitchell, Andrew A. Samwick, and Thomas L. Steinmeier. 1999. "Pension and Social Security Wealth in the Health and Retirement Study". In J. Smith and R. Willis, editors. Wealth, Work and Health, Innovations in Measurement in the Social Sciences. Ann Arbor: University of Michigan Press, pp. 150-207.

Gustman, Alan L. and Thomas L. Steinmeier, 2001a. “Imperfect Knowledge, Retirement and Behavior”. NBER Working Paper 8406.

Gustman, Alan L. and Thomas L. Steinmeier 2000. "Retirement Outcomes in the Health and Retirement Study”. Social Security Bulletin, Perspectives, 2000, volume 64, No. 4. 
Gustman, Alan L. and Thomas L. Steinmeier. 2001b. “What People Don’t Know About Their Pensions and Social Security.” In William G. Gale, John B. Shoven and Mark J. Warshawsky, editors, Public Policies and Private Pensions. Washington, D.C.: Brookings Institution, forthcoming.

Engen, Eric, and William Gale. 1999. “The Adequacy of Retirement Saving.” Brookings Papers on Economic Activity 2:65-165.

Engen, Eric, William Gale, and Cori Ucello. 2004. "Lifetime Earnings, Social Security Benefits, and the Adequacy of Retirement Wealth Accumulation.” CRR WP 2004-10. April.

Haider, Steven and Melvin Stephens Jr. 2004. “Is There a Retirement-Consumption Puzzle? Evidence Using Subjective Retirement Expectations.” NBER WP 10257 February.

Hurd, Michael and Susann Rohwedder. 2003. “The Retirement-Consumption Puzzle: Anticipated and Actual Declines in Spending at Retirement.” NBER WP 9586.

Kotlikoff, Laurence J. and Avia Spivak. 1981. "The Family as an Incomplete Annuities Market." Journal of Political Economy. April. 89(2) April" 372-91.

Kotlikoff, Lawrence J., Avia Spivak, and L. Summers. 1982. “The Adequacy of Savings.” AER. December 72(5): 1065-1069.

Lumsdaine, Robin and Olivia S. Mitchell. 1999. "New Developments in the Economics of Retirement”. In Handbook of Labor Economics. Eds. Orley Ashenfelter and David Card. Amsterdam: North Holland: 3261-3308.

McGill, Dan M., Kyle N. Brown, John J. Haley, and Sylvester J. Schieber, 2004. Fundamentals of Private Pensions , $8^{\text {th }}$ edition. Oxford: Oxford University Press. 
Mitchell, Olivia S., James Moore, and John Phillips. 2000. “Explaining Retirement Saving Shortfalls”. In Forecasting Retirement Needs and Retirement Wealth. Eds. O.S. Mitchell, B. Hammond, \& A. Rappaport. Philadelphia, PA: Univ. of Pennsylvania Press: 139-166. Mitchell, Olivia S. and James Moore. 1998. "Can Americans Afford to Retire? New Evidence on Retirement Saving Adequacy”. Journal of Risk and Insurance, 65 (3) December: 371-400.

Mitchell, Olivia S. and John W. R. Phillips. 2000. “Retirement Responses to Early Social Security Benefit Reductions”. NBER Working Paper \#7963, National Bureau of Economic Research, Cambridge, MA. October.

Moore, James and Olivia S. Mitchell. 2000. "Projected Retirement Wealth and Saving Adequacy”. In Forecasting Retirement Needs and Retirement Wealth. Eds. O.S. Mitchell, B. Hammond, and A. Rappaport. Philadelphia, PA: Univ. of Pennsylvania Press: 68-94. Sabelhaus, John, and Joyce Manchester. 1995. "Baby Boomers and Their Parents: How Does Their Economic Well-Being Compare in Middle Age?" Journal of Human Resources 30(4):791-806.

Scholz, John Karl, Ananth Seshadri, and Surachai Khitatrakun. 2003. “Are Americans Saving Optimally for Retirement?” University of Wisconsin Dept. of Economics Working Paper. Venti, Steven F. and David A. Wise. 2001. “Aging and Housing Equity: Another Look” NBER Working Paper No. 8608. 
Table 1: Saving Shortfalls by Wealth and Income Quintiles

\begin{tabular}{|c|c|c|c|c|c|c|c|}
\hline \multicolumn{4}{|c|}{ BY WEALTH QUINTILE } & \multicolumn{4}{|c|}{ BY EARNINGS QUINTILE } \\
\hline $\begin{array}{l}\text { Wealth } \\
\text { Quintile }\end{array}$ & $\begin{array}{l}\text { Median } \\
\text { Household } \\
\text { Wealth }\end{array}$ & $\begin{array}{c}\text { Median } \\
\text { Saving } \\
\text { Rate to } \\
\text { Age } 62 \\
(\%)\end{array}$ & $\begin{array}{c}\text { Median Saving } \\
\text { Rate to Age } 65 \\
\text { (\%) }\end{array}$ & $\begin{array}{l}\text { Earnings } \\
\text { Quintile }\end{array}$ & $\begin{array}{l}\text { Median } \\
\text { Household } \\
\text { Earnings }\end{array}$ & $\begin{array}{c}\text { Median } \\
\text { Saving } \\
\text { Rate to Age } \\
62(\%)\end{array}$ & $\begin{array}{c}\text { Median } \\
\text { Saving } \\
\text { Rate to Age } \\
65(\%)\end{array}$ \\
\hline \multicolumn{4}{|c|}{ Married } & \multicolumn{4}{|c|}{ Married } \\
\hline 1 & $\$ 207,432$ & 31 & 22 & 1 & $\$ 12,066$ & -60 & -67 \\
\hline 2 & $\$ 369,398$ & 22 & 13 & 2 & $\$ 31,475$ & 8 & -1 \\
\hline 3 & $\$ 539,739$ & 17 & 10 & 3 & $\$ 49,049$ & 17 & 9 \\
\hline 4 & $\$ 813,367$ & 7 & 0 & 4 & $\$ 68,197$ & 18 & 10 \\
\hline 5 & $\$ 1,431,411$ & -14 & -22 & 5 & $\$ 108,459$ & 20 & 13 \\
\hline \multicolumn{4}{|c|}{ Nonmarried } & \multicolumn{4}{|c|}{ Nonmarried } \\
\hline 1 & $\$ 64,433$ & 38 & 27 & 1 & $\$ 5,246$ & -19 & -29 \\
\hline 2 & $\$ 119,593$ & 33 & 21 & 2 & $\$ 15,738$ & 23 & 10 \\
\hline 3 & $\$ 207,249$ & 24 & 10 & 3 & $\$ 24,918$ & 28 & 14 \\
\hline 4 & $\$ 357,575$ & 10 & -4 & 4 & $\$ 35,410$ & 19 & 4 \\
\hline 5 & $\$ 696,247$ & -6 & -25 & 5 & $\$ 59,016$ & 14 & -2 \\
\hline Total & $\$ 506,668$ & 14 & 5 & Total & $\$ 45,902$ & 14 & 5 \\
\hline
\end{tabular}

Source: Authors' weighted computations from the HRS in \$2003. 
Table 2: Factors Associated with Probability of Working at Age 62 and 65: Nonmarried Sample

\begin{tabular}{|c|c|c|c|c|c|c|}
\hline \multirow{2}{*}{ Variable Name } & \multicolumn{3}{|c|}{$\mathrm{P}($ Work | 62) } & \multicolumn{3}{|c|}{ P(Work | 65) } \\
\hline & $X_{1}$ & $X_{1}, X_{2}$ & $\mathrm{X}_{1}, \mathrm{X}_{2}, \mathrm{X}_{3}$ & $X_{1}$ & $\mathrm{X}_{1}, \mathrm{X}_{2}$ & $\mathrm{X}_{1}, \mathrm{X}_{2}, \mathrm{X}_{3}$ \\
\hline \multirow[t]{2}{*}{ SAVE } & $0.00420^{* \star}$ & $0.00451^{* *}$ & $0.00434^{\star *}$ & $0.00188^{* *}$ & $0.00239^{* *}$ & $0.00157^{\star *}$ \\
\hline & [0.00008] & [0.00008] & [0.00008] & {$[0.00006]$} & {$[0.00006]$} & {$[0.00007]$} \\
\hline \multirow[t]{2}{*}{ SAVEDIFF } & $0.01210^{* *}$ & $0.01291^{* *}$ & $0.00332^{* *}$ & -- & -- & -- \\
\hline & [0.00059] & [0.00059] & {$[0.00061]$} & -- & -- & - \\
\hline \multirow[t]{2}{*}{ Less than HS } & $-0.08602^{\star *}$ & $-0.08437^{* *}$ & $-0.07008^{* *}$ & $-0.03725^{\star *}$ & $-0.04107^{* *}$ & $-0.00947^{* *}$ \\
\hline & {$[0.00094]$} & {$[0.00095]$} & [0.00099] & [0.00084] & {$[0.00083]$} & {$[0.00081]$} \\
\hline \multirow[t]{2}{*}{ More than HS } & $0.04024^{\star *}$ & $0.03380^{* *}$ & $0.03665^{\star *}$ & $0.00705^{\star \star}$ & $0.00623^{* *}$ & $-0.01585^{\star *}$ \\
\hline & {$[0.00075]$} & {$[0.00076]$} & {$[0.00080]$} & {$[0.00070]$} & {$[0.00071]$} & [0.00064] \\
\hline \multirow[t]{2}{*}{ Divorce } & $0.03929^{* *}$ & $0.03589^{* *}$ & $0.01748^{* *}$ & $0.01314^{* *}$ & $0.01755^{* *}$ & 0.000 \\
\hline & {$[0.00078]$} & {$[0.00078]$} & {$[0.00082]$} & {$[0.00073]$} & {$[0.00074]$} & [0.00068] \\
\hline \multirow[t]{2}{*}{ Widow } & $-0.00957^{* *}$ & $-0.01030^{* *}$ & $-0.06647^{* *}$ & $0.06367^{* *}$ & $0.06530^{* *}$ & $0.00238^{* *}$ \\
\hline & {$[0.00086]$} & {$[0.00086]$} & {$[0.00090]$} & [0.00083] & {$[0.00083]$} & {$[0.00072]$} \\
\hline \multirow[t]{2}{*}{ Children } & $0.00207^{* *}$ & $0.00285^{\star *}$ & $0.01452^{* *}$ & $0.00063^{\star *}$ & 0.000 & $0.00851^{* *}$ \\
\hline & {$[0.00019]$} & {$[0.00020]$} & {$[0.00021]$} & {$[0.00018]$} & {$[0.00018]$} & {$[0.00016]$} \\
\hline \multirow[t]{2}{*}{ Black } & $-0.00384^{\star *}$ & 0.001 & $0.01750^{\star *}$ & $0.01544^{* *}$ & $0.01949^{* *}$ & $0.01530^{* *}$ \\
\hline & {$[0.00091]$} & {$[0.00091]$} & {$[0.00095]$} & {$[0.00086]$} & {$[0.00087]$} & {$[0.00081]$} \\
\hline \multirow[t]{2}{*}{ Hispanic } & $0.07129^{\star *}$ & $0.08217^{* *}$ & $0.08638^{* *}$ & $-0.04569^{\star *}$ & $-0.04361^{* *}$ & 0.001 \\
\hline & {$[0.00149]$} & {$[0.00149]$} & [0.00159] & {$[0.00144]$} & {$[0.00146]$} & {$[0.00151]$} \\
\hline \multirow[t]{2}{*}{ Any ADL } & $-0.06359^{* *}$ & $-0.05910^{* *}$ & $0.03734^{\star *}$ & $-0.14533^{* *}$ & $-0.14594^{* *}$ & $-0.09290^{* *}$ \\
\hline & {$[0.00147]$} & {$[0.00148]$} & {$[0.00160]$} & {$[0.00097]$} & {$[0.00097]$} & [0.00094] \\
\hline \multirow[t]{2}{*}{$\begin{array}{l}\text { Subj. Prob } \\
\text { (Live to 75) }\end{array}$} & $0.09461^{* *}$ & $0.08529^{* *}$ & $0.05194^{* *}$ & $0.07827^{* *}$ & $0.07089^{\star *}$ & $0.04227^{\star *}$ \\
\hline & {$[0.00115]$} & {$[0.00116]$} & [0.00122] & {$[0.00110]$} & [0.00111] & [0.00102] \\
\hline \multirow[t]{2}{*}{ Female } & $0.14073^{* *}$ & $0.14525^{\star *}$ & $0.12636^{\star \star}$ & $0.05678^{* *}$ & $0.05959^{* *}$ & $0.00761^{* *}$ \\
\hline & {$[0.00072]$} & [0.00073] & {$[0.00076]$} & {$[0.00067]$} & {$[0.00067]$} & {$[0.00064]$} \\
\hline \multirow[t]{2}{*}{ Consume Less } & & $0.00851^{* *}$ & $0.02023^{* *}$ & & $-0.04133^{\star *}$ & $-0.00764^{\star *}$ \\
\hline & & {$[0.00072]$} & {$[0.00076]$} & & {$[0.00066]$} & {$[0.00061]$} \\
\hline \multirow[t]{2}{*}{ Long Plan } & & $0.06080^{* *}$ & $0.05114^{* *}$ & & $0.01103^{\star *}$ & $0.00201^{* *}$ \\
\hline & & {$[0.00069]$} & [0.00073] & & [0.00066] & [0.00059] \\
\hline \multirow[t]{2}{*}{ Health Shock } & & & $-0.25951^{* *}$ & & & $-0.13366^{* *}$ \\
\hline & & & {$[0.00078]$} & & & [0.00054] \\
\hline \multirow[t]{2}{*}{ Widow Shock } & & & $-0.50633^{* *}$ & & & $-0.19731^{* *}$ \\
\hline & & & {$[0.00080]$} & & & {$[0.00052]$} \\
\hline Observations & 947 & 947 & 947 & 787 & 787 & 787 \\
\hline Log Likelihood & -1618644.2 & -1614687.9 & -1473169.9 & -1084108.9 & -1080838.1 & -908744.3 \\
\hline
\end{tabular}

Note: Estimates are Probit marginal effects. Standard errors in parentheses. * denotes significant at $5 \%$ level; ** significant at $1 \%$ level. Also included are missing data flags for all right-hand side variables.

Source: Authors' weighted computations from the HRS. 
Table 3a: Factors Associated with the Probability of Working at Age 62: Married Sample

\begin{tabular}{|c|c|c|c|c|c|c|}
\hline \multirow{3}{*}{ Variable Name } & \multicolumn{6}{|c|}{ P(Work | 62) } \\
\hline & \multicolumn{2}{|c|}{$X_{1}$} & \multicolumn{2}{|c|}{$\mathrm{X}_{1}, \mathrm{X}_{2}$} & \multicolumn{2}{|c|}{$X_{1}, X_{2}, X_{3}$} \\
\hline & Respondent & Spouse & Respondent & Spouse & Respondent & Spouse \\
\hline \multirow[t]{2}{*}{ SAVE } & -0.00566 & & -0.00389 & & -0.00496 & \\
\hline & {$[0.00388]$} & & {$[0.00390]$} & & [0.00401] & \\
\hline \multirow[t]{2}{*}{ SAVEDIFF } & -0.00126 & & -0.00177 & & -0.00956 & \\
\hline & [0.04104] & & [0.04074] & & [0.04144] & \\
\hline \multirow[t]{2}{*}{ Less than HS } & -0.02758 & -0.01263 & -0.02436 & -0.02026 & -0.01971 & -0.01706 \\
\hline & {$[0.03150]$} & {$[0.03104]$} & [0.03168] & [0.03123] & {$[0.03351]$} & [0.03262] \\
\hline \multirow[t]{2}{*}{ More than HS } & $0.08908^{* *}$ & -0.0426 & $0.09623^{* *}$ & -0.0403 & $0.08223^{* *}$ & -0.04409 \\
\hline & {$[0.02354]$} & [0.02396] & {$[0.02356]$} & [0.02401] & {$[0.02423]$} & [0.02463] \\
\hline \multirow[t]{2}{*}{ Divorce } & -0.01627 & -0.02553 & -0.0145 & -0.03721 & -0.02219 & -0.03104 \\
\hline & {$[0.03161]$} & [0.03254] & {$[0.03177]$} & [0.03272] & [0.03227] & {$[0.03330]$} \\
\hline \multirow[t]{2}{*}{ Widow } & -0.12138 & -0.04282 & -0.11063 & -0.0641 & -0.11125 & -0.05599 \\
\hline & {$[0.06336]$} & [0.05852] & [0.06409] & [0.05916] & [0.06897] & [0.05799] \\
\hline \multirow[t]{2}{*}{ Children } & 0.00137 & & 0.00143 & & 0.00586 & \\
\hline & [0.00573] & & {$[0.00572]$} & & {$[0.00578]$} & \\
\hline \multirow[t]{2}{*}{ Black } & -0.04561 & 0.03097 & -0.0698 & 0.05379 & -0.04533 & 0.0055 \\
\hline & [0.10362] & [0.10235] & [0.10213] & {$[0.10050]$} & [0.10129] & {$[0.10050]$} \\
\hline \multirow[t]{2}{*}{ Hispanic } & -0.10251 & 0.09921 & -0.1072 & 0.11079 & -0.08967 & 0.08714 \\
\hline & [0.07045] & {$[0.07051]$} & {$[0.07027]$} & [0.06948] & {$[0.07157]$} & [0.07272] \\
\hline \multirow[t]{2}{*}{ Any ADL } & $-0.10065^{\star}$ & $0.10982^{* *}$ & $-0.11495^{*}$ & $0.09979^{* *}$ & -0.05885 & $0.10531^{* *}$ \\
\hline & [0.05079] & [0.03769] & [0.05088] & [0.03773] & [0.05556] & [0.03913] \\
\hline \multirow[t]{2}{*}{$\begin{array}{l}\text { Subj. P(Live to } \\
75)\end{array}$} & $0.12343^{* *}$ & -0.02429 & $0.14392^{* *}$ & -0.01633 & $0.10345^{*}$ & -0.02541 \\
\hline & {$[0.03832]$} & {$[0.03827]$} & {$[0.03861]$} & [0.03854] & {$[0.04034]$} & [0.03936] \\
\hline \multirow[t]{2}{*}{ Female } & $-0.09548^{* *}$ & & $-0.11888^{* *}$ & & $-0.12427^{\star *}$ & \\
\hline & {$[0.02111]$} & & {$[0.02164]$} & & {$[0.02221]$} & \\
\hline \multirow[t]{2}{*}{ Consume Less } & & & $0.05969^{* *}$ & 0.02908 & $0.07972^{* *}$ & 0.02541 \\
\hline & & & [0.02285] & [0.02401] & [0.02389] & [0.02519] \\
\hline \multirow[t]{2}{*}{ Long Plan } & & & $-0.04843^{*}$ & -0.00716 & $-0.04619^{*}$ & -0.00913 \\
\hline & & & [0.02148] & [0.02147] & {$[0.02214]$} & [0.02214] \\
\hline \multirow[t]{2}{*}{ Health Shock } & & & & & $-0.32939^{* *}$ & -0.02244 \\
\hline & & & & & {$[0.02408]$} & [0.02988] \\
\hline \multirow[t]{2}{*}{ Widow Shock } & & & & & $-0.26899^{* *}$ & \\
\hline & & & & & {$[0.05631]$} & \\
\hline Observations & \multicolumn{2}{|c|}{2900} & \multicolumn{2}{|c|}{2900} & \multicolumn{2}{|c|}{2900} \\
\hline Log Likelihood & \multicolumn{2}{|c|}{-4873716.4} & \multicolumn{2}{|c|}{-4822156.8} & \multicolumn{2}{|c|}{-4514345.4} \\
\hline
\end{tabular}

Note: Estimates are Probit marginal effects. Standard errors in parentheses. * denotes significant at $5 \%$ level; ** significant at $1 \%$ level. Also included are missing data flags for all right-hand side variables.

Source: Authors' weighted computations from the HRS. 
Table 3b: Factors Associated with the Probability of Working at Age 65: Married Sample

\begin{tabular}{|c|c|c|c|c|c|c|}
\hline \multirow{3}{*}{ Variable Name } & \multicolumn{6}{|c|}{$\mathrm{P}($ Work | 65) } \\
\hline & \multicolumn{2}{|c|}{$X_{1}$} & \multicolumn{2}{|c|}{$\mathrm{X}_{1}, \mathrm{X}_{2}$} & \multicolumn{2}{|c|}{$X_{1}, X_{2}, X_{3}$} \\
\hline & Respondent & Spouse & Respondent & Spouse & Respondent & Spouse \\
\hline \multirow[t]{2}{*}{ SAVE } & -0.00088 & & 0.00081 & & -0.00077 & \\
\hline & [0.00303] & & {$[0.00345]$} & & [0.00288] & \\
\hline \multirow[t]{2}{*}{ Less than HS } & -0.01896 & -0.00279 & -0.01639 & -0.00658 & -0.01352 & -0.01836 \\
\hline & {$[0.02698]$} & {$[0.02747]$} & {$[0.02712]$} & {$[0.02732]$} & [0.02703] & [0.02572] \\
\hline \multirow[t]{2}{*}{ More than HS } & $0.05784^{* *}$ & -0.02826 & $0.05977^{* *}$ & -0.0279 & $0.05036^{*}$ & -0.03642 \\
\hline & {$[0.02138]$} & [0.02073] & {$[0.02135]$} & [0.02063] & {$[0.02100]$} & [0.02008] \\
\hline \multirow[t]{2}{*}{ Divorce } & 0.02423 & -0.00514 & 0.02572 & -0.01214 & 0.02575 & -0.00984 \\
\hline & [0.02799] & [0.02869] & {$[0.02778]$} & {$[0.02788]$} & {$[0.02741]$} & {$[0.02718]$} \\
\hline \multirow[t]{2}{*}{ Widow } & -0.04541 & $-0.08142^{*}$ & -0.04143 & $-0.09357^{\star *}$ & -0.05399 & $-0.08947^{* *}$ \\
\hline & {$[0.05446]$} & {$[0.03835]$} & {$[0.05372]$} & {$[0.03479]$} & [0.04969] & {$[0.03356]$} \\
\hline \multirow[t]{2}{*}{ Children } & 0.00865 & & 0.00909 & & $0.01104^{*}$ & \\
\hline & [0.00524] & & [0.00528] & & [0.00486] & \\
\hline \multirow[t]{2}{*}{ Black } & -0.03366 & 0.06651 & -0.05918 & 0.09297 & -0.04325 & 0.06321 \\
\hline & [0.10498] & [0.13326] & [0.09382] & [0.13741] & [0.08843] & [0.12002] \\
\hline \multirow[t]{2}{*}{ Hispanic } & $-0.11222^{* *}$ & $0.18818^{*}$ & $-0.11551^{* *}$ & $0.20376^{*}$ & $-0.09878^{* *}$ & $0.17377^{*}$ \\
\hline & {$[0.03530]$} & [0.07924] & [0.03389] & {$[0.08016]$} & [0.03335] & [0.07538] \\
\hline \multirow[t]{2}{*}{ Any ADL } & -0.03493 & $0.09258^{*}$ & -0.0441 & $0.08773^{*}$ & -0.02201 & 0.07582 \\
\hline & {$[0.04594]$} & [0.04189] & [0.04394] & {$[0.04081]$} & {$[0.04508]$} & {$[0.03891]$} \\
\hline \multirow[t]{2}{*}{$\begin{array}{l}\text { Subj. P(Live to } \\
\text { 75) }\end{array}$} & 0.04787 & -0.04804 & 0.05514 & -0.04331 & 0.02672 & -0.04042 \\
\hline & {$[0.03410]$} & [0.03479] & {$[0.03422]$} & {$[0.03455]$} & {$[0.03342]$} & {$[0.03300]$} \\
\hline \multirow[t]{2}{*}{ Female } & $-0.05379^{\star *}$ & & $-0.06298^{\star *}$ & & $-0.06104^{* *}$ & \\
\hline & [0.01835] & & [0.01866] & & {$[0.01811]$} & \\
\hline \multirow[t]{2}{*}{ Consume Less } & & & 0.01098 & 0.0085 & 0.01919 & 0.00966 \\
\hline & & & {$[0.02091]$} & [0.02172] & {$[0.02086]$} & [0.02152] \\
\hline \multirow[t]{2}{*}{ Long Plan } & & & $-0.03797^{*}$ & 0.00178 & -0.02737 & 0.00077 \\
\hline & & & [0.01838] & {$[0.01870]$} & {$[0.01821]$} & [0.01849] \\
\hline \multirow[t]{2}{*}{ Health Shock } & & & & & $-0.13439^{* *}$ & -0.03187 \\
\hline & & & & & {$[0.01664]$} & [0.02264] \\
\hline \multirow[t]{2}{*}{ Widow Shock } & & & & & 0.06997 & \\
\hline & & & & & {$[0.04952]$} & \\
\hline Observations & \multicolumn{2}{|c|}{2425} & \multicolumn{2}{|c|}{2425} & \multicolumn{2}{|c|}{2425} \\
\hline Log Likelihood & \multicolumn{2}{|c|}{-2958680.8} & \multicolumn{2}{|c|}{-2920246.1} & \multicolumn{2}{|c|}{-2802235.2} \\
\hline
\end{tabular}

Note: Estimates are Probit marginal effects. Standard errors in parentheses. ${ }^{*}$ denotes significant at $5 \%$ level; ${ }^{*}$ significant at $1 \%$ level. Also included are missing data flags for all right-hand side variables.

Source: Authors' weighted computations from the HRS. 
Figure 1: Distribution of Shortfalls at Ages 62 and 65

Source: Authors' computations using STATA 8.0 SE univariate kernel density estimator (KDENSITY) of HRS shortfalls at age 62 and 65.

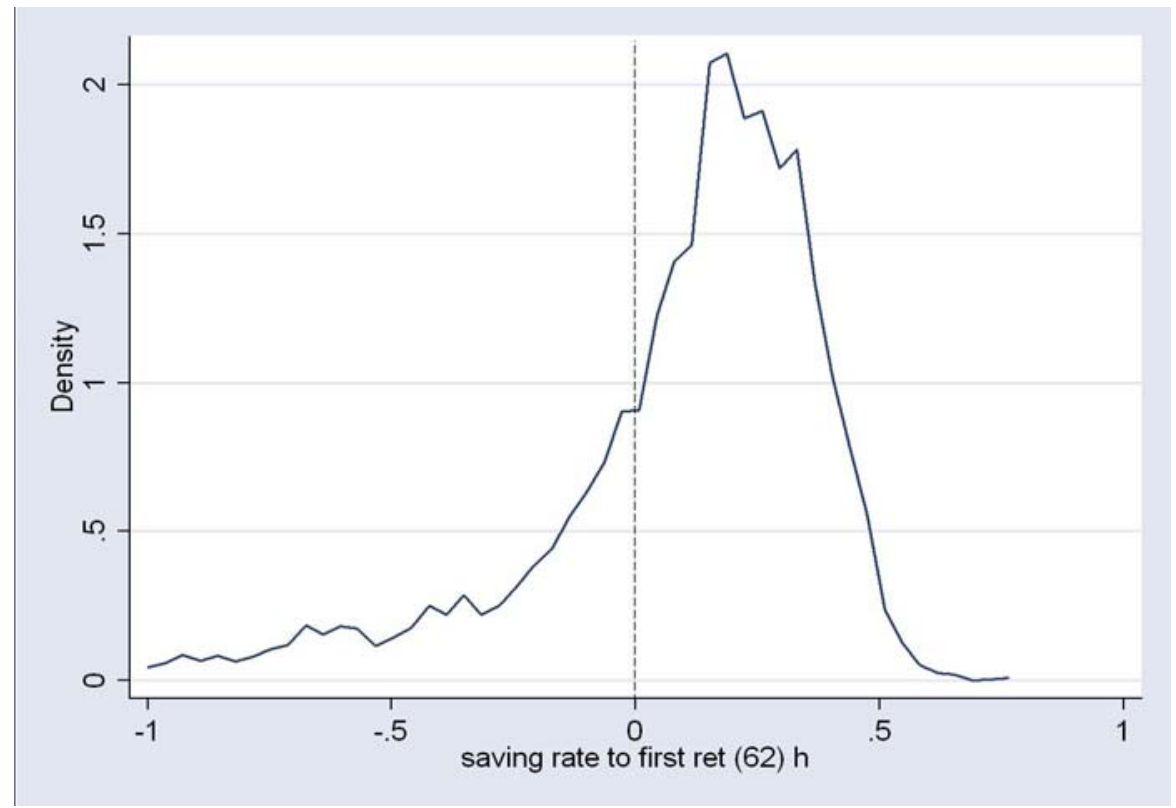

A. Saving Shortfalls for Retirement at Age 62: $67 \%$ have positive shortfall

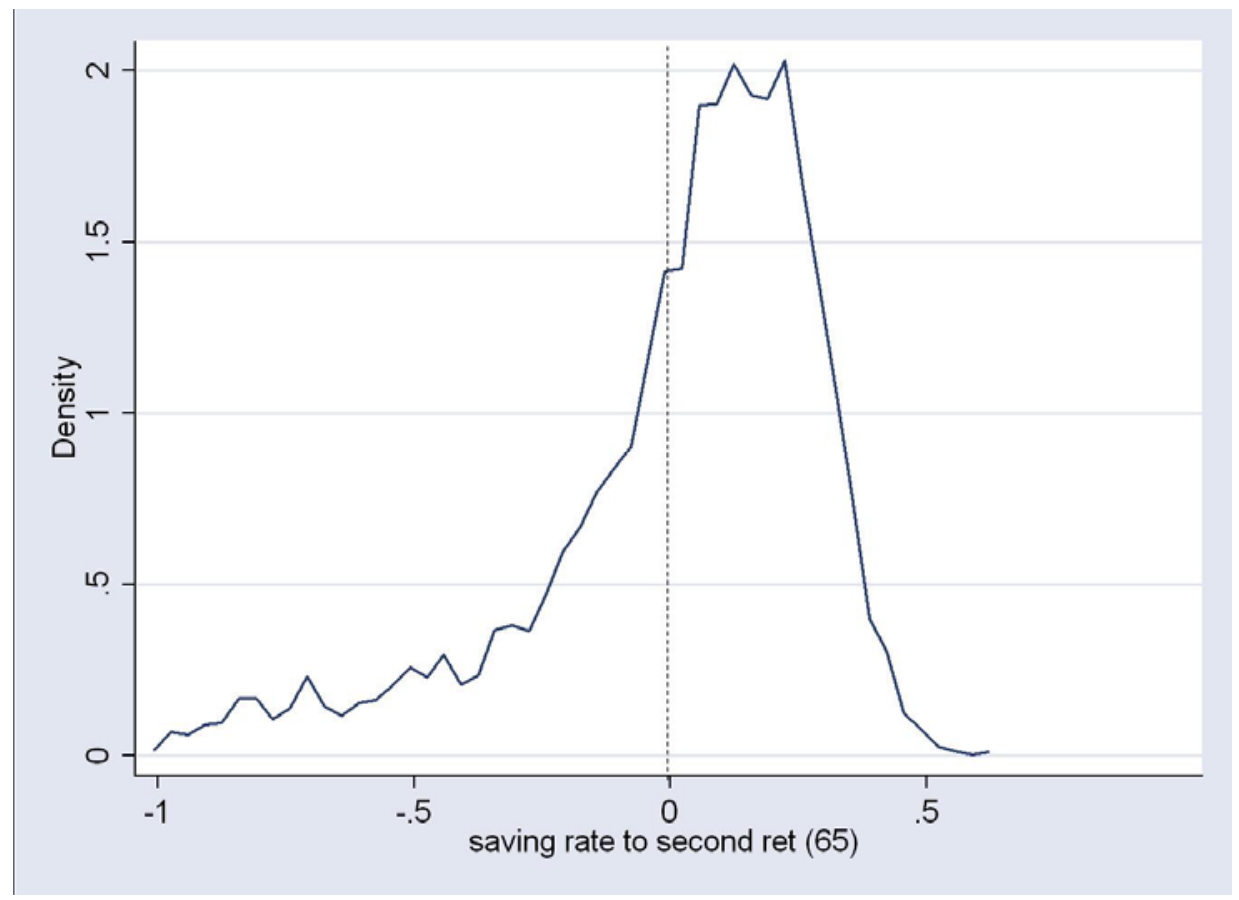

B. Saving Shortfalls for Retirement at Age $65: 58 \%$ have positive shortfall 
Figure 2: Ex-Ante and Ex-Post Probability of Work at Ages 62 and 65

Ex-Ante v. Ex-Post Pr(Work|Age) - Nonmarried

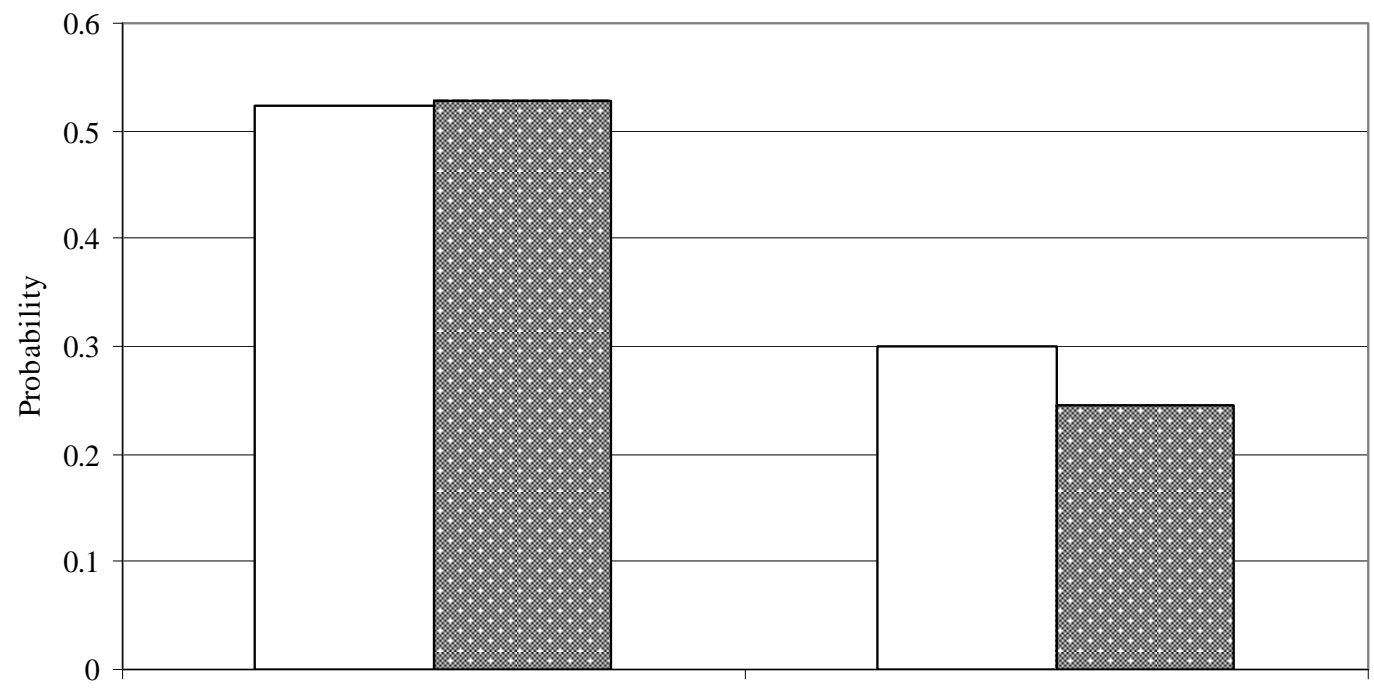

62 65

Age

Ex-Ante v. Ex-Post Pr(Work|Age) - Married

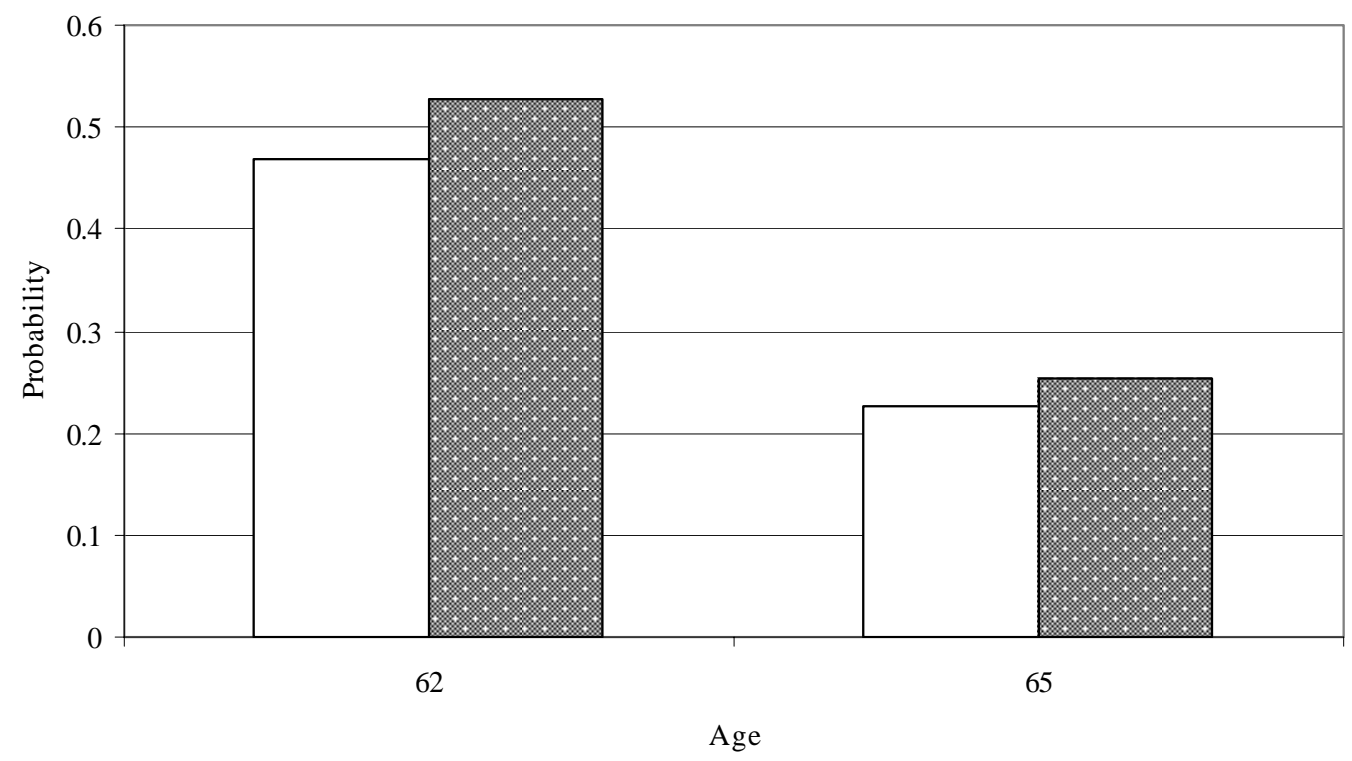

$\square$ Ex-Ante Pr(Work|Age) 圈 Ex-Post Pr(Work|Age)

Source: Authors’ weighted computations from the HRS. 
Figure 3: Effects of Savings Shortfall on the Predicted Probability of Work

Effect of Savings Shortfall on Predicted Probability of Working at Age 62 - Nonmarrieds

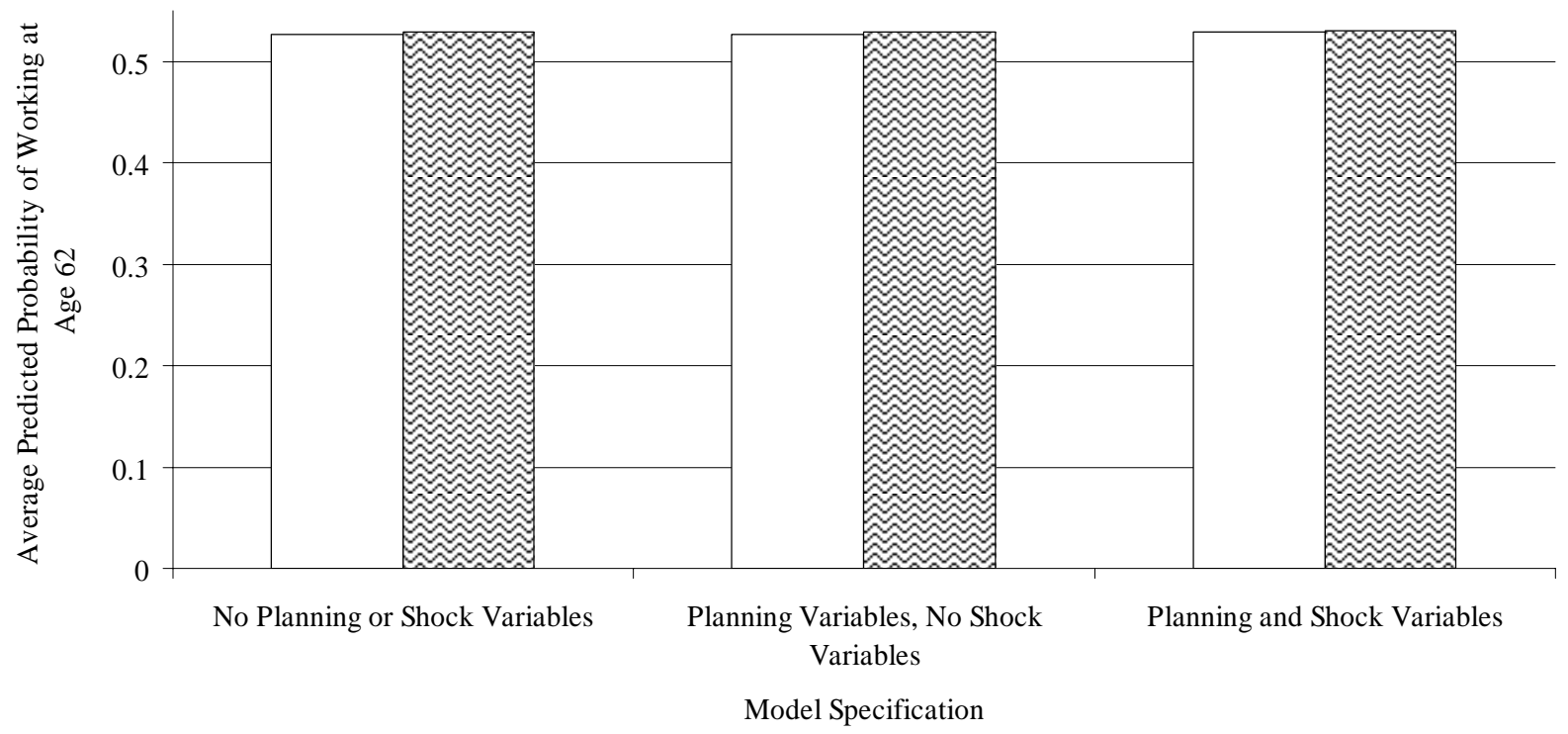

Effect of Savings Shortfall on Predicted Probability of Working at Age 65 - Nonmarrieds

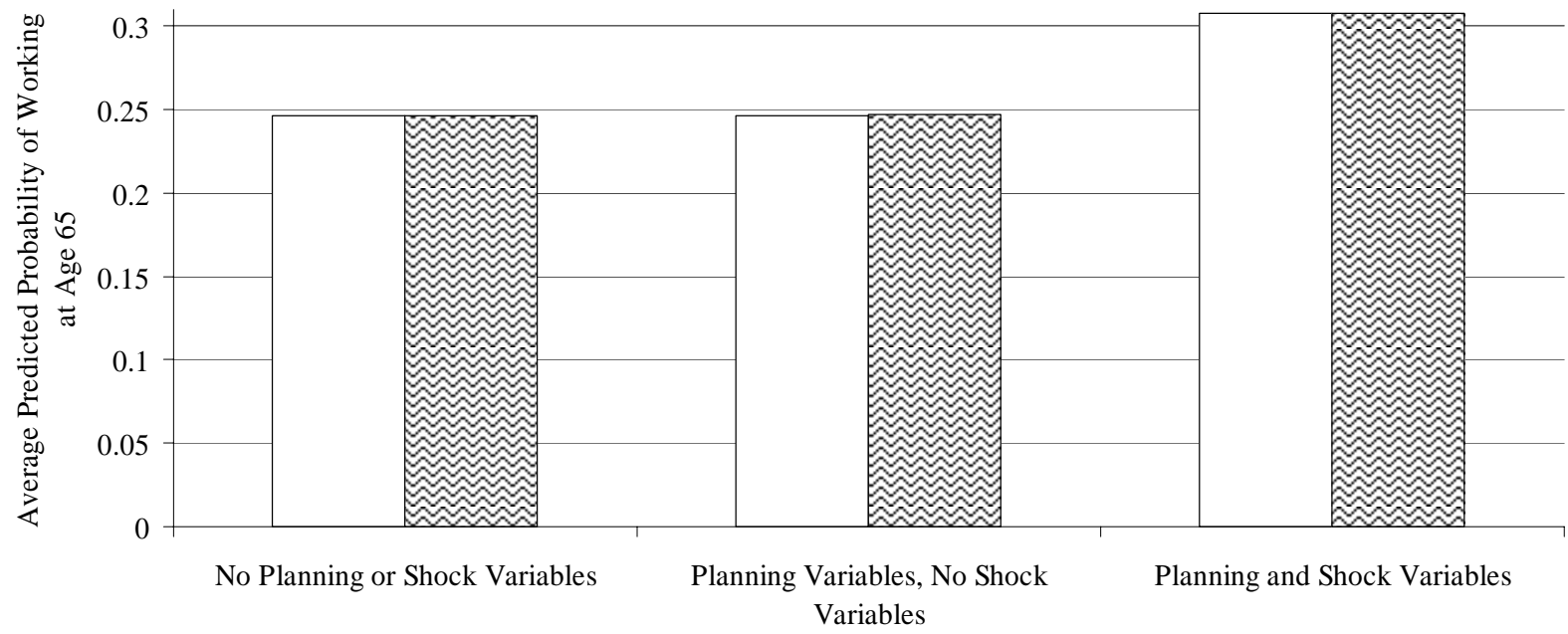

Model Specification

$\square$ Shortfall=0, Savediff=0 Q Shortfall=Median Shortfall, Savediff=Median Savediff

Source: Authors' weighted computations from the HRS. 
Appendix Table 1: Variable Definitions

\begin{tabular}{|c|c|c|}
\hline Variable Type & Variable Name & Description \\
\hline $\begin{array}{l}\text { Dep. } \\
\text { Variables }\end{array}$ & $\begin{array}{l}\text { W62PAY } \\
\text { W65PAY }\end{array}$ & \multirow{2}{*}{$\begin{array}{l}==1 \text { if } R \text { still working at age } 62 \\
==1 \text { if } R \text { still working at age } 65 \\
\text { (saving rate to age } 62)^{*} 100 \\
\text { (saving rate to age } 65)^{*} 100 \\
=(\text { save62)-(save65) }\end{array}$} \\
\hline Shortfalls $\left(X_{1}\right)$ & $\begin{array}{l}\text { SAVE62 } \\
\text { SAVE65 } \\
\text { SAVEDIFF } \\
\end{array}$ & \\
\hline SES $\left(X_{1}\right)$ & $\begin{array}{l}\text { Less than HS } \\
\text { More than HS } \\
\text { Divorce } \\
\text { Widow } \\
\text { Children } \\
\text { Black } \\
\text { Hispanic } \\
\text { Female }\end{array}$ & $\begin{array}{l}==1 \text { if } \mathrm{R} \text { has less than a high school education } \\
==1 \text { if } \mathrm{R} \text { has some college or more education } \\
==1 \text { if } \mathrm{R} \text { ever divorced prior to } 1992 \\
==1 \text { if } \mathrm{R} \text { ever widowed prior to } 1992 \\
\mathrm{~N} \text { children in household in } 1992 \\
==1 \text { if } \mathrm{R} \text { Black } \\
==1 \text { if } \mathrm{R} \text { Hispanic } \\
==1 \text { if } \mathrm{R} \text { female }\end{array}$ \\
\hline Health $\left(X_{1}\right)$ & $\begin{array}{l}\text { ANYADL } \\
\text { P(Live to 75) }\end{array}$ & $\begin{array}{l}==1 \text { if } R \text { reports trouble with } \geq 1 \text { ADL in } 1992 \\
R \text { subjective probability of living to age } 75 \text { in } 1992\end{array}$ \\
\hline Planning $\left(\mathrm{X}_{2}\right)$ & $\begin{array}{l}\text { Consume Less } \\
\text { Long Plan }\end{array}$ & $\begin{array}{l}==1 \text { if } R \text { expects a decrease in living standards after } \\
\text { retirement } \\
==1 \text { if } R \text { reports a long ( }>5 \text { yrs) financial planning } \\
\text { horizon in } 1992\end{array}$ \\
\hline "Shocks" ( $\left.\mathrm{X}_{3}\right)$ & $\begin{array}{l}\text { Health Shock } \\
\text { Widow Shock }\end{array}$ & $\begin{array}{l}==1 \text { if } R \text { did not report health as work limiting factor } \\
\text { in } 1992 \text {, but reported a work limiting health problem } \\
\text { after } 1992 \text { in some year prior to retirement } \\
==1 \text { if } R \text { widowed after } 1992 \text { and before the wave } \\
\text { that retirement }\end{array}$ \\
\hline
\end{tabular}

Notes: In married regressions, equivalent variables used for spouses.

Source: Authors' weighted computations from the HRS. 
Appendix Table 2: Summary Statistics for Unmarried Respondents by Analysis Sample

\begin{tabular}{|c|c|c|c|c|c|c|c|}
\hline \multirow{2}{*}{ Variable Type } & \multirow{2}{*}{ Variable Name } & \multicolumn{3}{|c|}{$\mathrm{P}($ Work | 62) Sample } & \multicolumn{3}{|c|}{ P(Work | 65) Sample } \\
\hline & & Mean & Std. Dev & $\%$ Missing & Mean & Std. Dev & $\%$ Missing \\
\hline Dependent Variable & W62(65)Pay & 0.53 & 0.50 & 0 & 0.24 & 0.43 & 0 \\
\hline Shortfalls $\left(X_{1}\right)$ & $\begin{array}{l}\text { SAVE } \\
\text { SAVEDIFF }\end{array}$ & $\begin{array}{l}-0.55 \\
0.19 \\
\end{array}$ & $\begin{array}{l}5.76 \\
0.77 \\
\end{array}$ & $\begin{array}{l}0 \\
0\end{array}$ & -0.80 & 6.64 & 0 \\
\hline $\operatorname{SES}\left(X_{1}\right)$ & $\begin{array}{l}\text { Less than HS } \\
\text { More than HS } \\
\text { Divorce } \\
\text { Widow } \\
\text { Children } \\
\text { Black } \\
\text { Hispanic } \\
\text { Female }\end{array}$ & $\begin{array}{l}0.20 \\
0.45 \\
0.57 \\
0.29 \\
2.45 \\
0.17 \\
0.05 \\
0.66 \\
\end{array}$ & $\begin{array}{l}0.40 \\
0.50 \\
0.50 \\
0.45 \\
1.86 \\
0.37 \\
0.22 \\
0.47 \\
\end{array}$ & $\begin{array}{l}0 \\
0 \\
0 \\
0 \\
0 \\
0 \\
0 \\
0\end{array}$ & $\begin{array}{l}0.21 \\
0.45 \\
0.57 \\
0.31 \\
2.46 \\
0.17 \\
0.05 \\
0.66 \\
\end{array}$ & $\begin{array}{l}0.41 \\
0.50 \\
0.50 \\
0.46 \\
1.92 \\
0.37 \\
0.21 \\
0.48 \\
\end{array}$ & $\begin{array}{l}0 \\
0 \\
0 \\
0 \\
0 \\
0 \\
0 \\
0\end{array}$ \\
\hline Health $\left(\mathrm{X}_{1}\right)$ & $\begin{array}{l}\text { Any ADL } \\
\text { Subj. P(Live to } \\
\text { 75) }\end{array}$ & $\begin{array}{l}0.05 \\
0.67 \\
\end{array}$ & $\begin{array}{l}0.23 \\
0.29 \\
\end{array}$ & $\begin{array}{l}0 \\
0 \\
\end{array}$ & $\begin{array}{l}0.06 \\
0.66 \\
\end{array}$ & $\begin{array}{l}0.24 \\
0.29 \\
\end{array}$ & $\begin{array}{l}0 \\
0 \\
\end{array}$ \\
\hline Planning $\left(X_{2}\right)$ & $\begin{array}{l}\text { Consume Less } \\
\text { Long Plan }\end{array}$ & $\begin{array}{l}0.47 \\
0.37\end{array}$ & $\begin{array}{l}0.50 \\
0.48\end{array}$ & $\begin{array}{c}0.16 \\
0 \\
\end{array}$ & $\begin{array}{l}0.46 \\
0.35 \\
\end{array}$ & $\begin{array}{l}0.50 \\
0.48\end{array}$ & $\begin{array}{c}0.16 \\
0 \\
\end{array}$ \\
\hline Shocks $\left(X_{3}\right)$ & $\begin{array}{l}\text { Health Shock } \\
\text { Widow Shock }\end{array}$ & $\begin{array}{l}0.25 \\
0.06 \\
\end{array}$ & $\begin{array}{l}0.43 \\
0.24\end{array}$ & $\begin{array}{l}0.09 \\
0.01\end{array}$ & $\begin{array}{l}0.35 \\
0.15\end{array}$ & $\begin{array}{l}0.48 \\
0.36\end{array}$ & $\begin{array}{l}0.31 \\
0.20\end{array}$ \\
\hline & Obs & 947 & & & 787 & & \\
\hline
\end{tabular}

Source: Authors' weighted computations from the HRS. 


\section{Appendix Table 3: Summary Statistics for Married Respondents by Analysis Sample}

\begin{tabular}{|c|c|c|c|c|c|c|c|c|c|c|c|c|c|}
\hline \multirow{3}{*}{ Variable Type } & \multirow{3}{*}{ Variable Name } & \multicolumn{6}{|c|}{ P(Work | 62) Sample } & \multicolumn{6}{|c|}{ P(Work | 65) Sample } \\
\hline & & \multicolumn{3}{|c|}{ Respondent } & \multicolumn{3}{|c|}{ Spouse } & \multicolumn{3}{|c|}{ Respondent } & \multicolumn{3}{|c|}{ Spouse } \\
\hline & & Mean & Std. Dev & $\%$ Missing & Mean & Std. Dev & $\%$ Missing & Mean & Std. Dev & Pct. Missing & Mean & Std. Dev & Pct. Missing \\
\hline Dep. Variable & W62(65)Pay & 0.53 & 0.50 & 0 & 0.51 & 0.50 & 0.12 & 0.25 & 0.43 & 0 & 0.39 & 0.49 & 0.36 \\
\hline Shortfalls $\left(X_{1}\right)$ & $\begin{array}{l}\text { SAVE } \\
\text { SAVEDIFF }\end{array}$ & $\begin{array}{l}-0.31 \\
0.09 \\
\end{array}$ & $\begin{array}{l}2.92 \\
0.30 \\
\end{array}$ & $\begin{array}{l}0 \\
0 \\
\end{array}$ & & & & -0.44 & 3.07 & 0 & & & \\
\hline $\operatorname{SES}\left(X_{1}\right)$ & $\begin{array}{l}\text { Less than HS } \\
\text { More than HS } \\
\text { Divorce } \\
\text { Widow } \\
\text { Children } \\
\text { Black } \\
\text { Hispanic } \\
\text { Female }\end{array}$ & $\begin{array}{l}0.17 \\
0.44 \\
0.23 \\
0.03 \\
3.42 \\
0.06 \\
0.04 \\
0.41 \\
\end{array}$ & $\begin{array}{l}0.37 \\
0.50 \\
0.42 \\
0.17 \\
1.94 \\
0.24 \\
0.20 \\
0.49 \\
\end{array}$ & $\begin{array}{l}0 \\
0 \\
0 \\
0 \\
0 \\
0 \\
0 \\
0\end{array}$ & $\begin{array}{l}0.17 \\
0.42 \\
0.21 \\
0.04 \\
\\
0.06 \\
0.04\end{array}$ & $\begin{array}{l}0.37 \\
0.49 \\
0.41 \\
0.20 \\
\\
0.24 \\
0.20\end{array}$ & $\begin{array}{l}0 \\
0 \\
0 \\
0\end{array}$ & $\begin{array}{l}0.17 \\
0.42 \\
0.23 \\
0.03 \\
3.46 \\
0.06 \\
0.04 \\
0.42 \\
\end{array}$ & $\begin{array}{l}0.38 \\
0.49 \\
0.42 \\
0.18 \\
1.96 \\
0.24 \\
0.20 \\
0.49 \\
\end{array}$ & $\begin{array}{l}0 \\
0 \\
0 \\
0 \\
0 \\
0 \\
0 \\
0\end{array}$ & $\begin{array}{l}0.17 \\
0.41 \\
0.21 \\
0.04 \\
\\
0.06 \\
0.04\end{array}$ & $\begin{array}{l}0.38 \\
0.49 \\
0.41 \\
0.20 \\
0.24 \\
0.19\end{array}$ & $\begin{array}{l}0 \\
0 \\
0 \\
0 \\
0 \\
0\end{array}$ \\
\hline Health $\left(X_{1}\right)$ & $\begin{array}{l}\text { Any ADL } \\
\text { Subj. P(Live to } \\
75)\end{array}$ & $\begin{array}{l}0.04 \\
0.67\end{array}$ & $\begin{array}{l}0.20 \\
0.27\end{array}$ & $\begin{array}{l}0 \\
0\end{array}$ & $\begin{array}{l}0.08 \\
0.68\end{array}$ & $\begin{array}{l}0.26 \\
0.27\end{array}$ & $\begin{array}{l}0 \\
0\end{array}$ & $\begin{array}{l}0.04 \\
0.66 \\
\end{array}$ & $\begin{array}{l}0.20 \\
0.28 \\
\end{array}$ & $\begin{array}{l}0 \\
0\end{array}$ & $\begin{array}{l}0.07 \\
0.67\end{array}$ & $\begin{array}{l}0.26 \\
0.27\end{array}$ & $\begin{array}{l}0 \\
0 \\
\end{array}$ \\
\hline Planning $\left(\mathrm{X}_{2}\right)$ & $\begin{array}{l}\text { Consume Less } \\
\text { Long Plan }\end{array}$ & $\begin{array}{l}0.42 \\
0.41\end{array}$ & $\begin{array}{l}0.49 \\
0.49\end{array}$ & $\begin{array}{c}0.13 \\
0 \\
\end{array}$ & $\begin{array}{l}0.45 \\
0.40\end{array}$ & $\begin{array}{l}0.50 \\
0.49\end{array}$ & $\begin{array}{c}0.23 \\
0 \\
\end{array}$ & $\begin{array}{l}0.42 \\
0.40\end{array}$ & $\begin{array}{l}0.49 \\
0.49\end{array}$ & $\begin{array}{c}0.12 \\
0 \\
\end{array}$ & $\begin{array}{l}0.45 \\
0.39\end{array}$ & $\begin{array}{l}0.50 \\
0.49\end{array}$ & $\begin{array}{c}0.24 \\
0 \\
\end{array}$ \\
\hline Shocks $\left(X_{3}\right)$ & $\begin{array}{l}\text { Health Shock } \\
\text { Widow Shock }\end{array}$ & $\begin{array}{l}0.22 \\
0.08 \\
\end{array}$ & $\begin{array}{l}0.41 \\
0.27 \\
\end{array}$ & $\begin{array}{l}0.09 \\
0.01 \\
\end{array}$ & 0.22 & 0.41 & 0.19 & $\begin{array}{l}0.31 \\
0.16 \\
\end{array}$ & $\begin{array}{l}0.46 \\
0.37 \\
\end{array}$ & $\begin{array}{l}0.32 \\
0.22 \\
\end{array}$ & 0.29 & 0.45 & 0.41 \\
\hline & Obs & 2900 & & & 2900 & & & 2425 & & & 2425 & & \\
\hline
\end{tabular}

Source: Authors' weighted computations from the HRS. 